Giulia Ballerini, $P h D$ student,

Bocconi University, Italy

Roberto Sacchi, Full Professor of Corporate and Bankruptcy Law (diritto commerciale), Università degli Studi di Milano, Italy

\title{
CONFLICT OF INTEREST AND CREDITORS' VOTE IN PREVENTIVE RESTRUCTURING FRAMEWORKS ${ }^{1}$
}

\section{INTEREŠU KONFLIKTS UN KREDITORU BALSOJUMS PREVENTİVĀS PĀRSTRUKTURĒŠANAS SISTĒMĀS}

\begin{abstract}
Kopsavilkums
Rakstā apskatīts interešu konflikta jautājums kreditoru balsojumā preventīvās pārstrukturēšanas sistēmās. Galvenā uzmanība pievērsta Itālijai raksturīgajai pārstrukturēšanas sistēmai, salīdzinot to ar ASV un Vācijas sistēmu (ņemot vērā arī Eiropas Savienības direktīvu par preventīvās pārstrukturēšanas regulējumu). Raksturoti dažādi kreditoru balsojumos iespējami interešu konflikta veidi, ieskicētas iespējamās juridiskās stratēgeijas to pārvaldīšanai. Dažādu kategoriju izveidošana un atbilstoša to pārraudzība ir piemērots lïdzeklis to interešu konfliktu novēršanai, kuri rodas dažādiem kreditoriem tipisku interešu atšķ̧irību dēḷ. Ja interešu konflikta iemesls ir noteiktu kreditoru netipiskas intereses (piemēram, ar parādnieku saistītu kreditoru), vēlams iejaukties individuālā balsojuma līmenī. Šajā gadījumā intervencei individuālā balsojuma līmenī vajadzētu būt ierobežošanai, nevis balsošanas aizliegumam, īpaši tāpēc, ka balsošanas aizliegums interešu konflikta atklāšanas rezultātā var radīt nevēlamu iznākumu (pārmērīgs vai nepietiekams prevencijas līdzeklis). Tā vietā, ja kreditors var balsot, neraugoties uz interešu konfliktu, un tiesai ir atḷauts kontrolēt šì kreditora balsojuma pamatotỉbu (t. i., tā lēmuma pamatotỉbu, kas pien,emts, pateicoties šì kreditora balsojumam) tikai tad, kad šis balsojums ir izškirošs, visi interešu konflikta gadījumi, pat visnenozīmīgākie, tiek pārtverti, savukārt pušu autonomija tiek upurēta tikai visnopietnākajos gadījumos, t. i., kad interešu konflikta rezultātā pieņemts kaitniecisks lēmums.
\end{abstract}

Atslēgvārdi: pārstrukturēšanas sistēmas, kreditoru balsojums, interešu konflikts, tiesiskās aizsardzības līdzekḷi

\section{Summary}

The paper addresses the issue of the conflict of interest in the creditors' vote in the preventive restructuring frameworks. The focus is on the Italian restructuring system, in a comparative perspective with the U.S. and German one (also taking into account the European Union Directive on restructuring frameworks). After having outlined the main factors influencing the matter, the different types of conflict of interest in the creditors' vote are described (conflict between interests that are typical of creditors as such and conflict between typical interest(s) of creditors as such and a creditor's atypical interest). Therefore, the possible legal strategies to manage them are outlined (class formation,

Although the work is the result of a shared discussion, Giulia Ballerini is the author of $\$ \$ 2.3,3,4$; Roberto Sacchi is the author of $\$ \$ 1,2.1,2.2$; both are co-authors of $\$ 5$. 
prohibition of vote, limitation of vote). The formation of different classes and the control that they are correctly formed is an adequate remedy for conflicts of interest arising from the differences of interests that are typical of creditors as such (e. g., financial vs. commercial creditors, secured vs. unsecured creditors). When the conflict of interest is instead due to the presence of atypical interests of certain creditors (e. g., a creditor linked to the debtor), it is preferable to intervene on the individual vote level, given that the formation of a special class does not prevent the vote in conflict of interest from being expressed and possibly decisive. In this case, the intervention on the individual vote level should be in terms of limitation instead of prohibition of voting. Indeed, the prohibition of voting as a consequence of detecting the conflict of interest produces undesirable outcome (overdeterrence or underdeterrence). Instead, if the creditor can vote despite the conflict of interest, and the court is allowed to control the merits of her vote (i.e. the merits of the decision taken thanks to her vote) only when her vote is decisive, all the cases of conflict of interest are intercepted, even the least serious, while the parties' autonomy is sacrificed only in the most serious cases, i. e. when the conflict of interest has produced a detrimental decision.

Keywords: restructuring frameworks, creditors' vote, conflict of interest, remedies

\section{Introduction}

This paper addresses the problem of the conflict of interest ${ }^{2}$ in the creditors' vote in the preventive restructuring frameworks. The focus will be on the Italian ${ }^{3}$ restructuring system ${ }^{4}$, especially after the adoption of the new Italian Bankruptcy Code, in a comparative perspective with the U.S. and the German system (taking into account the E.U. Directive on restructuring frameworks ${ }^{5}$ ). The problem is relevant because the conflict of interest can corrupt the creditors' vote and lead to abuses against minority creditors $^{6}$. This may put in jeopardy the principle of private autonomy, which, in its negative sense, does not tolerate interference of private individuals in the legal sphere

2 This concept is used here in a broad sense, including all cases when there are conflicting interests among claimants. For the definition of the various types of conflict, see below.

3 We take here into consideration both the current Italian Bankruptcy Code (Royal Decree no. 267/1942 and its amendments, hereinafter "IBC") and the new insolvency Code (hereinafter "CCI"), published in the Official Journal of Italian Laws on February 2019. It will enter into force in most of its parts in August 2020.

4 We will mainly refer here to the discipline of the arrangement with creditors (concordato preventivo or composition deed) under Articles 160 et seqq. IBC (Articles 84 et seqq. CCI). However, the same considerations expressed in relation to the arrangement with creditors could be applicable to other restructuring tools under Italian bankruptcy law, such as the out-of-court restructuring agreements (accordi di ristrutturazione dei debiti) under Articles 182-bis et seqq. IBC (Articles 57 et seqq. CCI).

5 Directive of the European Parliament and of the Council on preventive restructuring frameworks, on discharge of debt and disqualifications, and on measures to increase the efficiency of procedures concerning restructuring, insolvency and discharge of debt, and amending Directive (EU) 2017/1132. Available at: https://eur-lex.europa.eu/legal-content/EN/TXT/PDF/?uri=CELEX:32019L1023\&f rom=EN [last viewed 18.07.201š9.].

6 This problem also arises with regard to shareholders, in those systems (U.S., Germany) where shareholders can vote on the plan. Due to limitations of format, this aspect of the problem cannot be fully addressed here. However, since shareholders would vote ex latere creditoris, the observations made here with regard to the creditors' vote may apply to them, too. 
of other private individuals. In light of this, the majority principle is imperilled whenever the choice of the majority is contaminated by the presence of a conflict of interest.

This problem is influenced by various factors: (i) the balance achieved between public regulation ${ }^{7}$ and self-regulation ${ }^{8}$ (ii) the space reserved for creditors' decisions; (ii) the space reserved for the majority principle in the creditors' decisions.

In the article below, these factors will be examined separately, in order to outline how each one interacts with the issue. Afterwards, the types of conflicts of interest in the creditors' vote and the legal strategies to deal with them will be described. Finally, a proposal for a solution to the problem will be suggested.

\section{Public regulation vs self-regulation}

We speak of public regulation when the court has not only the power to verify the regularity of the procedure but can also decide on the merits of the restructuring solution $^{9}$. This is the case of the discipline originally provided for in the Italian Bankruptcy Code of 1942 (Article 181), which allowed the court to have a 'final say' on the merits of the plan, despite the approval of the plan by the creditors according to the required majorities. According to some authors, the court could exercise this power even in the event of unanimous agreement on the plan ${ }^{10}$.

Generally, when public regulation is given a substantial role, the risks associated with the conflict of interest of some creditors are reduced. In fact, even where the creditors' vote has been contaminated by the conflict of interest leading to the approval of a plan detrimental to some other creditors, the court will conduct an independent inquiry which may end up in refusal of that plan.

On the one hand, such an extensive power of intervention by the court can better counteract the conflict of interest; on the other, it has the cost - a relevant component in a market economy - of reducing the role of those who should be in the best position to assess their interests, i.e. the creditors.

Precisely for this reason, in the reforms of the first decade of this century, public regulation has been greatly reduced in the Italian restructuring system, which has become closer to the U.S. and German system, where the court plays a role, in this respect, when it comes to protecting dissenting minorities (in this case, the court will

\footnotetext{
7 This word is used here in the sense of regulation by the Law or the Courts.

This word is used here in the sense of parties' autonomy.

9 The Italian system distinguishes the concept of 'proposal' (the proposed agreement offered to the creditors) from the one of 'plan' (the concrete tool to implement the obligations contained in the proposal). For this distinction, see Fabiani M. Per la chiarezza delle idee su proposta, piano e domanda di concordato preventivo e riflessi sulla fattibilità. Fallimento, 2011, pp. 172-182. For simplicity, the word 'plan' is used here in a broad sense, including also the concept of 'proposal'.

10 See, e.g., Bonsignori A. Del concordato preventivo. In: Commentario Scialoja-Branca. La legge fallimentare, directed by Bricola F. et al, Bologna-Roma: Zanichelli-Società Editoriale del Foro Italiano, 1979 , p. 420.
} 
verify that certain fairness standards are met) ${ }^{11}$. In particular, with the 2005-2007 Reform in Italy ${ }^{12}$, the power to assess the merits of the arrangement was withdrawn from the court (but in case of qualified objection to the plan by creditors holding $20 \%$ of the voting claims or, when classes are formed, creditors belonging to dissenting classes $\left.^{13}\right)$ : the space for self-regulation is now broader.

\section{Space reserved for creditors' decisions}

Within self-regulation, the relevance of the conflict of interest is then influenced by the boundaries placed on the parties' autonomy. This may depend on the ultimate distribution standard adopted in the particular system. We are referring to the options whether the (surplus) value created by the plan can be freely distributed (as according to a certain interpretation of the Italian system ${ }^{14}$ ) or should instead be allocated according to a specific distribution rule, namely the absolute priority rule ("APR") ${ }^{15}$ (U.S. ${ }^{16}$, Germany ${ }^{17}$, Proposal for a Directive of November $2016^{18}$ ) or any another distribution rule, such as the E.U. "relative priority rule" (introduced, as an alternative to the APR, by the Council of the European Union in the Directive as a more flexible standard compared to the APR ${ }^{19}$ ). The APR defines a layered structure in the distribution of the value created in restructuring proceedings, pursuant to which higher ranked claimants must be paid in full before lower ranked claimants can get any value. The E.U. relative priority rule ("RPR") differs from the APR because it does not require that senior claimants are paid in full before junior claimants, but only that senior claimants are treated more favourably than junior claimants ${ }^{20}$. Given this

11 This doesn't mean that the democratic decision of the creditors is always decisive. The court has, e.g., the power to review the economic feasibility of the plan, which is provided for in all the three systems (in Italy, after the CCI). See $\$ 1129$ (a)(11) Chapter 11, Sections 231 and 245 InsO, Articles 47-48 CCI. See also Recital 50 and Article 10, paragraph 3 of the Directive.

12 Reform started with Law Decree No. 35/2005, converted into Law No. 80/2005.

13 See Article 180, paragraph 4, IBC (see also Article 112 CCI).

14 See, e. g., Fabiani M. Appunti sulla responsabilità patrimoniale «dinamica» e sulla de-concorsualizzazione del concordato preventivo. In: Fallimento, soluzioni negoziate della crisi e disciplina bancaria, directed by Ambrosini S. Bologna: Zanichelli, 2017, p. 41 et seqq.

15 In the U.S. and German system, the APR comes into play only when the plan fails to get the acceptance of all impaired classes. Therefore, if all classes agree, they can autonomously determine how to allocate the value among themselves. However, the bargaining dynamics are directly affected by the need to comply with the APR in cramdown.

$16 \$ 1129$ (b) Chapter 11.

17 Section 245(2)1 InsO.

18 Proposal for a Directive of the European Parliament and of the Council on preventive restructuring frameworks, second chance and measures to increase the efficiency of restructuring, insolvency and discharge procedures and amending Directive 2012/30/EU. Available at: https://eur-lex.europa.eu/ legal-content/EN/TXT/PDF/?uri=CELEX:52016PC0723\&from=EN [last viewed 29.05.2019.]. Article 11, paragraph 1, lett. (c).

19 See Article 11, paragraph 2a of the General Approach of 1 October 2018. Available at: http://data. consilium.europa.eu/doc/document/ST-12536-2018-INIT/en/pdf [last viewed 10.05.2019.].

20 And that dissenting voting classes of affected creditors are treated at least as favourably as any other class of the same rank. 
framework, it is clear that the fewer constraints the creditors have in deciding how to allocate the value created by the plan, the greater the risk of opportunistic behaviour and conflict of interest. In this perspective, the risk is maximum when creditors are left free to determine how to allocate the value created by the plan; it decreases if the RPR is adopted; it decreases further with the APR.

\section{Space reserved for the majority principle}

In general, the larger the space for the majority principle, the higher the risk that minority creditors will be harmed by the conflict of interest in the majority vote. From this point of view, there are important differences between the Italian system, on the one hand, and the German and U.S. system ${ }^{21}$, on the other. In the latter systems, the majority principle is actually applied within each class of creditors and interest holders, but the plan must be in principle approved by all the impaired classes (with the required majorities) ${ }^{22}$. If, however, one or more classes vote against the plan (nonconsensual plan), the court will overrule the dissenting class/classes (cramdown mechanism) only if some 'fairness' standards are met (including the APR). In Italy, instead, the requirement that all classes accept the plan is absent, being sufficient that the majority of the claims approves the plan in the majority of the classes (when classes are formed ${ }^{23}$ ). The space left to the majority principle is therefore wider and so is the risk of conflict of interest and opportunistic behaviour.

When classes are formed, the fact that the objecting creditor belongs to a consenting class should theoretically reassure, with respect to the risk of conflict of interest, since the majority of creditors in her class approved it. However, this only works if the classes have been correctly formed, i.e. if they have been formed on the basis of a similarity of both legal position and economic interests and the court is allowed to review it. The need to take into account not only the legal position but also the economic interests appears to be crucial in a system, such as the Italian one, in which: (i) the final decision whether to restructure or to proceed with bankruptcy liquidation (in the case of insolvent debtor) is in any case left to the majority of creditors, in the majority

${ }_{21}$ The same for the Directive on restructuring frameworks.

22 Article 1129(a)(8) Chapter 11 and Section 244 InsO.

23 Under the IBC, classes are not mandatory (Article $160 \mathrm{IBC}$ ). The new CCI introduces some cases of compulsory classes (Article 85, paragraph 5, CCI). 
of classes, if formed ${ }^{24}$; (ii) the control by the court that the individual creditor is not adversely affected by the plan is limited to cases of qualified objection ${ }^{25}$.

\section{The two possible conflicts}

In order to assess how to fight the conflict of interest in the voting of creditors, it is first necessary to identify which is the typical interest (or 'common interest') of creditors in the composition deed, i.e. the interest of creditors as such. Once this interest has been defined, it is possible to identify the conflicting interest with it. Before going on, it should be pointed out that the possibility of identifying a 'common interest' of creditors in the composition deed, and therefore the general possibility of a conflict of interest in the creditors' vote, was denied by Italian case-law until recently (Judgement of the Italian Supreme Court, case No. $3274 / 2011^{26}$ ). This is basically because, unlike in the case of companies, creditors in insolvency proceedings would not constitute a separate legal entity to which a 'common interest' could be linked. This interpretation was finally reversed by a recent decision of the Joint Sections of the Italian Supreme Court (Case: $17186 / 2018^{27}$ ), which, embracing the suggestions of some author ${ }^{28}$, has indeed recognized the general possibility of a conflict of interest in the composition deed.

As noted above, the problem of identifying the typical interest has often been addressed in company law with regard to the position of shareholders. Actually, the position of shareholders may be linked to more than one interest that is typical of their position (and therefore qualifiable as 'company's interest'), and these interests may be conflicting ones: for example, the interest in the distribution of dividends (typical of those shareholders who have invested in a short-term financial perspective) and the

${ }^{24}$ This is not the case in the U.S. system, where, in the case of a non-consensual plan (i.e. when there is no unanimity of the classes in favor of the plan), the consent of one class is sufficient to allow the restructuring of the business through the confirmation of the plan by the court in cramdown $(\$ 1129(\mathrm{a})(10)$ Chapter 11). In that system, if, on the one hand, the consent of one class plus the intervention of the court is enough to carry on the reorganization, on the other hand, the intervention of the court is always required when the unanimity of the classes in favor of the plan is missing. In Germany, instead, when the unanimity of the classes is missing, the majority of them is still required to approve the plan for the plan to be confirmed by the court in cramdown (Section 245(1)3 InsO). The Directive (Article 11) requires for confirmation of the plan in cramdown that the majority of the classes approve the plan 'or, failing that', that at least one of the voting classes approves the plan. In this last case, however, Member States may increase the minimum number of classes required to approve the plan.

25 In Italy, the creditor within a consenting class (or creditors holding less than $20 \%$ of the voting claims, when classes are not formed) is not entitled, as in the U.S. and Germany, to control by the court that the creditor receives at least what she would receive in liquidation (best interests of creditors test). This makes it necessary that only parties with the same interests, including economic interests, are grouped in the same class so that the decision is not affected by an asymmetry between the interests of the voting parties. As for the Directive, see Recital 52 and Article 10, paragraph 2, lett. (d).

26 Available in Giur. Comm., 2012, II, p. 276.

27 Available in Fallimento, 2018, p. 960.

28 See, e.g., Fabiani M. Contratto e processo nel concordato fallimentare. Torino: Utet Giuridica, 2009. Sacchi R. Dai soci di minoranza ai creditori di minoranza. Fallimento, 2009, pp. 1063-1073. 
one in their reinvestment (typical of those who have invested with a medium-term industrial logic). Both these interests can be abstractly ascribed to all shareholders (unless an extreme version of the theory of the "Shareholder Value" is accepted, under which the first interest will prevail over the second). In case of conflict between typical interests it is generally believed that the majority should decide which interest prevails over the other, within the limit of abuse of law, which occurs e.g. in case the lack of dividend distribution persists over a long time and has no business justification.

For the creditors in the composition deed the problem should theoretically be simpler: in this case, all creditors tend to have the same interest linked to their position as holders of claims towards the debtor's assets: to be paid as much as possible and as quickly as possible. a conflict between interests that are typical of creditors as such could, however, arise, for example, when creditors have to choose between a solution that provides for payment to a greater extent, but over a longer period of time, and one that provides for payment to a lesser extent, but over a shorter period of time. Here, again, the decision about which interest should prevail is to be left to the majority.

However, it should be borne in mind that, when a group takes its decisions by majority vote, the differences between the typical characteristics of the members of the group may result in majority decisions having asymmetrical effects on their typical interests. This situation is frequent in the joint-stock companies (s.p.a.), when the shares have different characteristics. Think of the case in which there are 100 shares, 40 of category $\mathrm{A}$, that have a full vote and a privilege in the distribution of dividends equal to $3 \%$ of the nominal value, 60 of category $B$, that have a full vote, but do not have that privilege. If a shareholders' meeting is called to amend the articles of association, lowering the privilege for category a shares from $3 \%$ to $2 \%$, there is an obvious conflict between the interests of category a shareholders and those of category B shareholders. This conflict is due to the asymmetric effect that the resolution produces for the interests (typical, as linked to the characteristics of the shares) of the two categories of shareholders; in this case, the Italian Civil Code solves the problem (Article 2376) by requiring a separate vote of the shareholders of the damaged category, that is, in our example, the shareholders with preferred shares (category a shareholders).

The situation referred to in the preceding paragraph may also arise for creditors as a result of the characteristics of their claims. Think, e.g., of those who are holders of credits having provided goods/services to the debtor. Given the characteristics of their claim, they will be encouraged to favour preventive restructuring frameworks that provide for the continuation of the business activity, in order to be able to continue to work in the future with the debtor company. Think, on the other hand, of a bank that has made an unsecured loan to a debtor: the bank may be anxious to cut its losses and may refuse to have future dealings with the debtor. In this case, there is a conflict of interest between creditors, which appears to be linked to their typical positions.

A qualitatively different hypothesis of conflict of interest arises if a creditor $\mathrm{X}$ has an atypical interest (i.e., an interest not related to his position as a creditor) in conflict with the typical interest(s) of creditors (including the same creditor X). Think of the 
case in which a creditor is a related party of the plan-proponent (regardless of whether this is the debtor or a creditor $\left.{ }^{29}\right)$.

\section{The different strategies to deal with the abovementioned conflicts}

After having identified the two types of conflict of interest in the creditors' vote, it is possible to examine the various strategies to counteract them. They are basically of two types: A) to require a separate vote for those who are affected by the conflict of interest; B) to intervene on the individual vote which is expressed in conflict of interest.

In the case of the composition deed, the first strategy (A) could be represented by the formation of classes. On this point, however, it is necessary to understand whether the formation of classes is to be perceived as a chance offered to the plan's 'architect' to make his proposal more attractive (by providing different classes with different treatments which favour those required to achieve the required majorities), or whether the classes represent a tool to fight the conflict of interest. Only if the problem is solved in this second sense, it is possible for the court to exercise a penetrating control over the formation (or lack of formation) of classes. In Italy, the majority opinion is in favour of the first meaning ${ }^{30}$. However, the new CCI seems to provide arguments in the second sense: see Article 85, paragraph 5, CCI on some cases of compulsory class formation. The fact that in some cases the formation of classes is imposed by law leads us to believe that they do not represent an opportunity given to the plan 'architect' to make the proposal more attractive but are instead a tool to fight the conflict of interest. If we accept this thesis, the court should be able to review in depth the criteria with which the classes were formed (or were not formed), even outside the new cases of compulsory classification expressly provided for by the CCI. In this perspective, the formation of classes can become a way of managing conflicts of interest linked to the different characteristics of claims (conflicts between typical interests of creditors as such) ${ }^{31}$. This strategy appears advisable in this case, because: the creditors with potentially

29 With regard to the new discipline provided for in the CCI, we note that there is a differential treatment between the related parties of the debtor, who are excluded from voting (Article 109, paragraph 5 , $\mathrm{CCI}$ ), and the creditor who files a competing plan and his related parties, who can vote, although they must be placed in a specific class (Article 109, paragraph 6, CCI); this solution treats the debtorproponent and the creditor-proponent differently: the former cannot vote on his plan or that of others, while the latter could vote on both his plan and that of the debtor, provided he is placed in a separate class.

30 See, e.g., Nardecchia G. B. Le classi e la tutela dei creditori nel concordato preventivo. Giur. Comm., 2011, II, pp. 87-88.

31 Although the Directive is not clear on this point, it contains elements that appear to confirm this view. See, for example, Recital 44, stating that Member States should "be able to require that more than two classes of creditors are formed, including different classes of unsecured or secured creditors and classes of creditors with subordinated claims. Member States should also be able to treat types of creditors that lack a sufficient commonality of interest, such as tax or social security authorities, in separate classes [...]. It should also be possible for Member States to lay down specific rules supporting class formation where non-diversified or otherwise especially vulnerable creditors, such as workers or small suppliers, would benefit from such class formation”. 
different typical interests can express their vote, even if grouped in different classes (on the basis of their typical interests), thus contributing to the overall threshold; however, the creditors' vote within the class cannot have asymmetrical effects on the members of that class (if classes are correctly formed).

With regard to the second technique (B), the intervention on the individual vote sterilizes the vote corrupted by the conflict of interest. In this respect, it is possible to use the strategy of limiting the vote (limitazione del voto) ${ }^{32}$ or of prohibiting the vote (divieto di voto) ${ }^{33}$. The intervention on the individual vote strategy differs from the 'class formation' because, while in the latter case the creditors vote anyway and may contribute to reach the consensus of the majority of the classes (in Italy) or of all the classes (U.S., Germany), in the former case creditors in conflict are prevented from voting (if the vote is prohibited), or they cannot vote in a way that is detrimental to the common interest (if there is a limitation to the vote). This strategy is advisable when there is a conflict between typical interest(s) of creditors as such and an atypical interest of some creditors. This is the case, for example, of Article 109, paragraph 5, CCI, which, among others, considers (in general terms and with a residual formula) the conflict of interest and provides for the prohibition of voting. The same strategy is suggested in the Directive, according to which "Member States may exclude from the right to vote" "any related party of the debtor or the debtor's business, with a conflict of interest under national law" (Article 9, paragraph 3, lett. (c)).

It would have been preferable, however, to use a vote's limitation instead of a prohibition. The vote's limitation strategy is used, for example, in the Italian Civil Code (Article 2373) to manage the shareholder's conflict of interest in the s.p.a. shareholders' meeting: in this case the shareholder in conflict of interest can vote, but the court can review her vote and annul the resolution if her vote is decisive and if the resolution (taken thanks to her vote) is potentially prejudicial to the company. This has allowed interpreters to adopt a broad notion of conflict of interest, referring not only to cases of absolute incompatibility between interests (the satisfaction of one interest excludes the satisfaction, even partial, of the other interest), but also to cases of relative incompatibility (when there is an interference of interests but the possibility of an incomplete realization of both conflicting interests remains). This makes it possible to monitor situations of conflict of interest in a broad way. In this way, the court can intervene (with a decision on the merits) in all cases in which there is some interference of interests, which however produce concrete effects (i. e. the invalidity of the resolution) only when the shareholder in conflict has made his atypical interest prevail, expressing a vote potentially prejudicial to the company.

In the CCI, on the other hand, where the vote is prohibited, interpreters are faced with a sharp alternative: (i) either a broad notion of conflict of interest is adopted, extending it to all cases of interference of interests; if this choice is adopted, there will be many cases of exclusion of creditors from voting, with a high cost for the parties'

32 This strategy implies that the creditor can vote, and the court will examine the merits of her vote if it is decisive; the court will then disqualify the vote if it finds out that this vote is detrimental to the 'common interest', which means that the creditor in conflict has made his atypical interest prevail.

33 This strategy implies that the creditor is ex ante excluded from the vote. 
autonomy; (ii) or, a restrictive notion of the conflict of interest is adopted, limiting it to cases of absolute incompatibility of interests (e. g., when the creditor is a related party to the plan proponent); in this case, all the hypotheses of relative incompatibility of interests remain without legal remedies.

It would therefore be preferable, with a view to legislative reform, if, in the event of a conflict between the typical interest(s) of the creditors as such and a creditor's atypical interest, the consequence was not the prohibition of voting, but the possibility for the court to disqualify the creditor's vote when: (i) the vote in conflict of interest is decisive, since it triggers the overall majority of the claims or (when classes are formed) the majority within the class and, in turn, the class is decisive for the achievement of the majority of the classes (in Italy) or the consent of all the classes (Germany, U.S.); (ii) it has actually led to a decision that is detrimental to the creditors, which means that the creditor in conflict of interest has made his atypical interest prevail. In this case, the court should examine the merits of the composition deed as voted with the determining vote of the creditor in conflict of interest, even where this would not be expressly permitted under the general rules of the applicable insolvency law (for example, in Italy, in the absence of qualified objection to the plan).

This proposal leads to results that are similar to the ones achievable in the U.S. system, where votes that are designated under $\$ 1126(\mathrm{e})$ Chapter 11 are excluded from the calculation. Specifically, on request of a party in interest, and after notice and a hearing, the court is empowered to designate any entity whose acceptance or rejection was "not in good faith". Courts have held that a vote should be disqualified when it is cast for a reason other than the creditor's desire to maximize its recovery on its claim $^{34}$, e.g. when there is an "ulterior motive". "An ulterior motive exists $[\ldots]$ when the creditor votes to further an interest unrelated to its interests as a creditor" 35 .

One last remark. As already mentioned, the Directive gives the Member States the option whether to use the strategy of prohibiting the vote in fighting the conflict of interest ("Member States may exclude from the right to vote..."). However, since this represents just an option for Member States (which may not adopt it), there is nothing to prevent the strategy of limiting the vote (here suggested) from being used. Indeed, omne majus continet in se minus.

\section{Conclusions}

1. It is preferable to manage the conflict of interest in the creditors' vote in the preventive restructuring frameworks with self-regulation instead of public regulation;

2. this, however, requires that adequate safeguards be provided against the risk that the conflict of interest contaminates the creditors' vote, especially in the Italian system, where the majority rule is given a more extensive space;

34 Frost C. W. Bankruptcy Voting and the Designation Power. American Bankruptcy Law Journal, Vol. 87, 2013, p. 155.

35 Ibid., p. 161. For completeness, see also $\$ 1129(a)(10)$. 
3. the most appropriate strategies to fight the conflict of interest are: 3.1) to group claimants with similar typical interests and to give the court a penetrating power of review that the classes are correctly formed (or non-formed); 3.2 ) to intervene on the single vote in the case of conflict between creditors' typical interests and a creditor's atypical interest; the intervention on the single vote level should consist in a vote's limitation (under the control of the court) instead of a vote's prohibition.

\section{BIBLIOGRAPHY}

\section{Literature}

1. Angelici C. et al. L'interesse sociale tra valorizzazione del capitale e protezione degli stakeholders. In ricordo di Pier Giusto Jaeger, Atti del Convegno - Milano, 9 October 2009, Milano: Giuffrè, 2010.

2. Arsalidou D. et al. Corporate Rescue. An Overview of Recent Developments. Gromek Broc K., Parry R. (eds.). Alphen aan den Rijn: Kluwer Law International, 2006.

3. Baird D. G. Elements of Bankruptcy. New York: Foundation Press, 2010.

4. Bork R. Einführung in das Insolvenzrecht. Tübingen: Mohr Siebeck, 2019.

5. Braun E., Frank A. Obstruktionsverbot. In: Insolvenzordnung (InsO). München: C. H. Beck, 2017, pp. 1120-1127.

6. Breuer W. Zurückweisung des Plans. In: Münchener Kommentar zur Insolvenzordnung. Band 3. München: C. H. Beck, 2014, pp. 312-318.

7. Christensen L. H. et al. Principles of European Insolvency Law, edited by McBryde W. W., Flessner A., Kortmann S. C. J. J. Deventer: Kluwer Legal Publishers, 2003.

8. D'Attorre G. Il voto nei concordati ed il conflitto d'interessi fra creditori. Fallimento, 2012, pp. $757-766$.

9. Eidenmüller H. Gesellschafterstellung und Insolvenzplan. ZGR, 2001, pp. 680-711.

10. Fabiani M. Contratto e processo nel concordato fallimentare. Torino: Utet Giuridica, 2009.

11. Ferri jr. G. et al. Diritto societario e crisi d'impresa, edited by Tombari U. Torino: Giappichelli, 2014.

12. Frost C. W. Bankruptcy Voting and the Designation Power. American Bankruptcy Law Journal, Vol. 87, 2013, pp. 155-189.

13. Jackson T. H. Bankruptcy, Non-Bankruptcy Entitlements, and the Creditors' Bargain. Yale Law Journal, Vol. 91, No. 5, 1982, pp. 857-907.

14. Jackson T. H. The Logic and Limits of Bankruptcy Law. Cambridge, Massachusetts-London, England: Harvard University Press, 1986.

15. Kraakman R. et al. The Anatomy of Corporate Law. Oxford: Oxford University Press, 2017.

16. Mokal R., Tirado I. Has Newton had his day? Relativity and realism in European Restructuring. Eurofenix, Winter 2018/2019, pp. 20-23.

17. Norberg S. F. Classification of Claims under Chapter 11 of the Bankruptcy Code: The Fallacy of Interest Based Classification. American Bankruptcy Law Journal, Vol. 69, 1995, pp. 119-166.

18. Stanghellini L., Mokal R., Paulus C. G., Tirado I. Best Practices in European Restructuring. Contractualised Distress Resolution in the Shadow of the Law. Milano: Wolters Kluwer-Cedam, 2018. 
19. Tabb C. J. Law of Bankruptcy. Hornbook Series. St. Paul, MN: West Academic Publishing, 2016.

20. Vattermoli D. Concordato con continuità aziendale, absolute priority rule e new value exception. Riv. dir. comm., 2014, II, pp. 331-357.

21. Weijs R. J., de. Harmonization of European Insolvency Law: Preventing Insolvency Law from Turning against Creditors by Upholding the Debt-Equity Divide. European Company and Financial Law Review, Vol. 15, Issue 2, 2018, pp. 403-444. 